\title{
Dominant plant species are the drivers of postindustrial sites ecosystem functioning
}

\author{
Karolina RYŚ ${ }^{1}$ - Agnieszka BŁOŃSKA ${ }^{1}$ - Wojciech BIERZA ${ }^{1}-$ Franco MAGURNO $^{1,2}$ \\ - Gabriela WOŹNIAK ${ }^{1}$ \\ 1: Department of Botany and Nature Protection; Faculty of Biology and Environmental Protection, University of \\ Silesia in Katowice, Jagiellońska 28, 40-032 Katowice, Poland; E-mail: gabriela.wozniak@us.edu.pl \\ 2: Centre of Mountain Environmental Technologis, Hołcyna 219, 43-438 Brenna, Poland
}

Keywords: dominant plant species, mass ratio hypothesis, coal mine spoil heaps, novel ecosystem, vegetation succession

\section{Introduction}

The vegetation developing systems that emerge on habitats recognized as novel ecosystems of Anthropocene (Hobbs et al. 2006), such as post-industrial sites, can be an opportunity to understand the links between the clue ecosystem elements like the dominant plant species and the abiotic and biotic substrate (anthroposols) conditions (Waters et al. 2016). Dominant species influence both vegetation as well as soil properties such as soil seed bank properties of the soil substrate. However, knowledge about the role played by dominant species in the process of shaping their habitat within post-industrial ecosystems is limited. Some study on dominant plant species has also been conducted on many habitats including post-industrial sites (Prach and Pyšek 1999, Woźniak 2010) and these studies have mostly been focused on the species composition that accompanies the dominant plants on a range of different types of post-industrial sites. The vegetation growing on coal mine spoil heaps consists of a mosaic of patches dominated by various species confined to a variety of microhabitats (Woźniak et al. 2015, Rawlik et al. 2018a, Rawlik et al. 2018b). We aimed to assess the role of some dominant species, expressed as their influence on soil substratum abiotic and biotic properties, and to assess the dominant species role in novel ecosystem function development.

\section{Materials and methods}

In the studies plots we have assessed the dominant species and the accompanying species biomass. We have assessed the above ground biodiversity by using various diversity indicators. We have measured soil chemistry, including the content of carbon, nitrogen, phosphorous potassium as well as sodium and magnesium content, conductivity, $\mathrm{pH}$ and enzyme activities as well as PLFA, species diversity and functional diversity of vegetation for each species studied.

\section{Results and discussion}

The spontaneous vegetation developing on post-industrial sites influenced both species and functional composition, as well as the chemical and biological properties of soil substratum. The primary vegetation types (plots dominated by Tussilago farfara) had the highest influence on post-industrial site habitats on coal mine heaps and the extreme values of some soil substratum parameters. The decrease of species and functional diversity of vegetation has been also recorded. The parameters of rhizosphere substrate samples under the dominant plant species has revealed differences in soil substratum organic matter 
content. While the content of potassium did not differ in the substrates from the studied vegetation patches, the rhizosphere soil substrate conditions in patches dominated by $D$. carota and $P$. compressa were statistically significantly different in terms of $\mathrm{Mg}$ content. About phosphorus content the highest value has been recorded for patches dominated by T. farfara and P. compressa. The study has provided results of analysis which revealed that dominant species in the spontaneous vegetation developing on post-industrial sites alters the chemical and biological properties of the post-industrial sites soil substratum. The species with the highest mean dominant biomass did not always cause lower biodiversity in vegetation patches. Some dominant plant species such as Tussilago farfara appeared to have the major impact on the habitat features on post-industrial sites. The highest impact of the soil substratum parameters were recorded as being extreme for other dominant plant species then the those dominant plant species for which the highest biodiversity values have been recorded.

\section{Conclusions}

The stages of the ecosystem development and the relationship between the biota (including vegetation types) in Novel Ecosystems did not follow the rules known for natural or seminatural vegetation. The results confirmed that the spontaneous development of novel ecosystems are barely understood and require additional research.

\section{Acknowledgement}

The study was part of the InfoRevita project TANGO ID:268600 financed by NCBiR

\section{References}

Hobbs, R.J., Arico, S., Aronson, J., Baron, J.S., Bridgewater, P., Cramer, V.A., Norton, D. et al. (2006): Novel ecosystems: theoretical and management aspects of the new ecological world order. Global Ecology and Biogeography. 15: 1. 1-7. DOI: https://doi.org/10.1111/j.1466-822X.2006.00212.x

Prach, K., Pyšek, P. (1999): How do species dominating in succession differ from others?. Journal of Vegetation Science. 10: 3. 383-392. DOI: https://doi.org/10.2307/3237067

Rawlik, M., Kasprowicz, M., Jagodziński, A.M. (2018a): Differentiation of herb layer vascular flora in reclaimed areas depends on the species composition of forest stands. Forest Ecology and Management. 409: 541-551. DOI: https://doi.org/10.1016/j.foreco.2017.11.055

Rawlik, M., Kasprowicz, M., Jagodziński, A.M., Kaźmierowski, C., Łukowiak, R., Grzebisz, W. (2018b): Canopy tree species determine herb layer biomass and species composition on a reclaimed mine spoil heap. Science of The Total Environment. 635: 1205-1214. DOI: https://doi.org/10.1016/j.scitotenv.2018.04.133

Waters, C.N., Zalasiewicz, J., Summerhayes, C., Barnosky, A.D., Poirier, C., Gałuszka, A., Cearreta, A. et al. (2016): The Anthropocene is functionally and stratigraphically distinct from the Holocene. Science. 351: 6269. aad2622. DOI: https://doi.org/10.1126/science.aad2622

Woźniak, G. (2010): Diversity of vegetation on coal-mine heaps of the Upper Silesia (Poland). Szafer Institute of Botany, Polish Academy of Sciences, Kraków.

Woźniak, G., Markowicz, A., Borymski, S., Piotrowska-Seget, Z., Chmura, D., Besenyei, L. (2015): The relationship between successional vascular plant assemblages and associated microbial communities on coal mine spoil heaps. Community Ecology. 16: 1. 23-32. DOI: https://doi.org/10.1556/168.2015.16.1.3 